Original paper

\title{
A Water-Energy-Food Nexus-Based Conceptual Approach for Developing Smart Urban-Rural Linkages in Nagpur Metropolitan Area, India
}

\author{
Vibhas Sukhwani $^{1 *}$ and Rajib Shaw ${ }^{1}$
}

Received: 25/02/2020 / Accepted: 10/07/2020 / Published online: 20/08/2020

\begin{abstract}
Urban and rural areas are dynamic systems, functionally interlinked through their social, economic, and environmental settings. While urban population heavily depends on the natural resources sourced from surrounding rural areas, the rural population is increasingly reliant on urban areas for employment, healthcare etc. In the recent years, the notion of urbanrural linkage has gained high prominence in the global policy outcomes, including the Sustainable Development Goals and The New Urban Agenda, particularly in response to the rapid urbanization trends and climate change. However, it's application at local level development planning is still not apparent. In case of the Nagpur Metropolitan Area 'NMA' in India, a Smart City and Smart Rural 'Rurban' Cluster are being developed adjacently under two different missions of Government of India which are totally disconnected. While urbanrural systems in NMA are already stressed with the situations of resource conflict (like water supply), their relationships are expected to get further constrained under changing climate scenarios. Addressing this need, we present a knowledge-based conceptual framework that presents an overall picture of the water resource flow (specifically from a Water-Energy-Food nexus perspective) between urban and rural areas within NMA. Based on the developed framework, the study suggests feasible directions for smartly linking the upcoming developments in Nagpur Smart city and adjacent Rurban cluster.
\end{abstract}

Key words: Urban-Rural linkages, Smart City, Rurban Cluster, Water-Energy-Food nexus, Integrated Disaster Risk Management, Nagpur

\footnotetext{
${ }^{1}$ Graduate School of Media and Governance, Keio University Shonan Fujisawa Campus, 5322 Endo, Fujisawa, Kanagawa Prefecture 252-0882, Japan

*Corresponding Author: Email: vibhas@sfc.keio.ac.jp; Tel.: +81-80-1352-5101 (Vibhas Sukhwani).
} 


\section{INTRODUCTION}

Smart developments, be it in urban or rural areas, are today becoming a global reality. While the concept of smart development is still evolving, there is no established definition as to what makes an urban or rural area 'smart'. A few researchers refer to smart developments as the integration of Information and Communication Technology 'ICT' features into daily life activities and state functions (Komninos 2011; Randhawa and Kumar 2017), while others emphasize on knowledge management (Garcia 2007). The definitions, nomenclatures and the context of smart developments differ from place to place. However, it is acknowledged that they contribute to the regional vision of smart growth (Blais 2003). In the broadest sense, the concept of 'Smart' is related to different structuring aspects of a society like Smart Economy, Smart People, Smart Environment, Smart Living, Smart Governance and Smart Mobility, with the key objective of enhancing quality of life in terms of reduced energy consumption, inclusive growth, cleaner transport etc. (Chichernea 2015; Kumar and Dahiya 2017).

In the wake of growing urban population and increasing concentration of economic activities, cities around the world are increasingly embracing technologies like sensors, cameras, wireless devices, data centres etc. to enhance the provision of services to urban residents in a faster and efficient manner. Noticeably, the application of ICT features in cities has been debated for a long time under different labels including Knowledge cities, Intelligent cities, Digital Cities, Virtual Cities etc., which are often used interchangeably (Meijer and Bolívar 2013). However, the concept of 'Smart Cities' (recognized since late 1990's) has today overshadowed all other concepts in terms of academic research and is globally been recognized as an umbrella term for enhancing livability, sustainability and quality of life in urban areas. In recent years, there have been several policy initiatives around the world for implementing the 'Smart cities' concept, as well as private sector initiatives (like from IBM and CISCO) for enabling technology integration into cities (Mora et al. 2017). Likewise, there are also several pilot projects been implemented to develop 'Smart Villages' through technology integration, which is a relatively new concept (several initiatives highlighted by Zavratnik et al. 2018).

While smart developments are increasingly focused on securing investments, creating more jobs etc., it is important to understand that their resource demands will proportionately increase with the growing population and economic activities. As cities depend on surrounding rural areas for most of their resource demands in terms of water, energy, food, manpower etc. (Wilbanks and Fernandez 2013; Morton et al. 2014; Sukhwani et al. 2019), it is highly important to strengthen the urban-rural linkages to safeguard the flow of key resources, especially in the wake of changing climatic conditions and emerging disaster risks. The importance of urban-rural linkages has also been recognized at the global policy level, including the Sustainable Development Goals 'SDGs' (UNDP 2015) and The New Urban Agenda (UN-Habitat 2017). However, there is very limited progress in their application at policy and governance levels. The discrete governance of urban and rural areas has also become a major cause of concern amidst the ongoing COVID-19 'Coronavirus disease 2019' global pandemic (officially declared by the World Health Organization on 11th March 2020), as urban 
and rural areas around the world have experienced increased isolation, with disrupted urbanrural supply chains (also discussed by Egal and Forster 2020).

In case of India, the development planning is moving forward with 'Smart Cities' under the Smart Cities Mission 'SCM' (SCM 2015) and 'Smart Rural clusters' (Rurban clusters) under the National Rurban Mission 'NRuM' (NRuM 2016). While SCM is focused on providing core infrastructure and improved quality of life to urban citizens, the NRuM is intended to complement the SCM by stimulating local economic development and enhancing basic services in rural areas with a cluster-based approach. Singh and Rahman (2018) explained that the definition of 'Rurban' cluster is not clearly defined under the NRuM, and it is often linked to peri-urban areas. However, in Indian context, the Rurban areas are increasingly been related to the rural areas that have urban amenities (Hui and Wescoat 2019). Moreover, both the development missions are been implemented separately in a disconnected manner. In case of Nagpur Metropolitan Area (NMA) in central India, Nagpur Smart city (Nagpur SCP 2016) and Wadoda Rurban cluster (Wadoda ICAP 2017) are being developed adjacently with no consideration to unintended mutual consequences. While Nagpur is being projected to be the fifth fastest growing city in the world from 2019-2035 (Holt 2018), it has recently experienced serious water stress concerns, across different sectors including urban domestic, industry, agriculture etc. (Deshkar 2019). Therefore, to ensure continued supply of water resources for sustainable development of Nagpur, it will be important to address the urban-rural linkages from a nexus perspective.

With that background, this study works towards identifying potential areas of shared concern in NMA where the upcoming smart developments can engage to foster urban-rural linkages. The three specific objectives of this research are as follows, (a) To study the action plans of ongoing Nagpur Smart City and Wadoda Rurban Cluster developments, and identify their key shortcomings; (b) To understand the flow of water resources between urban and rural areas in Nagpur Metropolitan Area (NMA), from a Water-Energy-Food (WEF) nexus perspective, (c) To suggest feasible directions for incorporating the component of 'urban-rural linkage' in the action plans of upcoming Smart City and Rurban Cluster in Nagpur region. It is important to note that this research will only focus on urban and rural areas as extreme ends of the continuum. To overcome the knowledge gaps on urban-rural linkages in NMA, this research builds on a knowledge-based conceptual framework of water resource flow between urban and rural areas, which is developed based on a literature review. For the context of this study, a 'knowledgebased' framework mainly refers to the notion of addressing the cross-sectoral linkages between different sectors (mainly WEF sectors) for achieving coordinated development planning.

The remaining paper is structured as follows. Section 2 provides a brief overview about the key concepts of urban-rural linkages, WEF nexus and knowledge-based approach. Section 3 introduces the case study area of NMA, and briefly explains the key characteristics and shortcomings in the upcoming smart urban-rural developments. The research methodology has been explained in Section 4. Section 5 elaborates on the independent flow of water, energy, and food resources between urban and rural areas in NMA, which are then interlinked to form a knowledge-based conceptual framework in Section 6. Building on the developed framework, Section 7 presents feasible measures to smartly link the upcoming smart urban-rural 
developments. The last Section 8 summarizes the key conclusions and underlines the key research limitations.

\section{LITERATURE REVIEW}

This section is intended to provide a precise understanding of the existing scientific literature, related to the key concepts that form the basis of the conducted research. The section is divided into three sub-sections. The first sub-section discusses about the concept of urban-rural linkages and their growing importance in the present policy context. The second sub-section explains about the growing relevance of WEF nexus thinking for strengthening urban-rural linkages at transboundary scale. The last sub-section deliberates on the idea of knowledgebased approach for development planning. For the literature review, relevant publications from selected database of Scopus along with the online grey literature and academic research were referred.

\subsection{Importance of Urban-Rural linkages}

Urban and rural areas are geographically dispersed, but they are closely linked through a variety of spatial and sectoral linkages (Tacoli 1998). Urban-rural linkages basically refer to the two-way flow of a variety of resource elements like food, energy, water, goods, information, finances, people, culture etc. (Douglass 1998; Akkoyunlu 2015). Rural areas have traditionally served as the center of key natural resources and labor, which are crucial to urban regions. Likewise, their urban counterpart areas provide markets for agricultural products, specialized services like healthcare, education, employment etc. It has been found that the definitions of urban and rural areas, based on various factors like demographic and economic criteria, vary in different countries (van Leeuwen and Nijkamp 2006). However, with changing population dynamics, expanding urban areas and changing land use patterns, the nature of urban-rural linkages is also reported to be fast-changing even within the same country. More and more productive agricultural lands, wetlands, forests etc. are been acquired for urban development purposes (also discussed by Sukhwani et al. 2019). Particularly in fast developing countries like India, which have a predominant rural population (68.84\% as per Census 2011), urban and rural areas within a regional space are increasingly interwoven. Over the years, a number of empirical studies have been conducted to study the changing dynamics of urban-rural linkages in India and globally (eg. Peeters and Marinho 2008; Bari and Munir 2014; Sivaramakrishnan and Sar 2014; Kim 2015). While majority of these studies have analysed the spatial level flow of resources, transportation connectivity has been identified as one of the key factors in shaping the urban-rural linkages.

At global policy level, the importance of urban-rural linkages has for long been recognized in development planning (UN-Habitat1976). However, the 2030 Agenda for Sustainable Development (UNDP 2015) and The New Urban Agenda (UN-Habitat 2017) have provided a 
renewed attention to this concept. Against the conventionally discrete governance structures of urban and rural areas, regional level planning exercises in consideration to urban-rural linkages have today become critical to maintain the environmental balance. Researchers have also pointed out that enhancing the connectedness between urban and rural areas has potential to reduce poverty, economic inequality and at the same time maintain the ecological and cultural diversity that are crucial for sustainable development (Srivastava and Shaw 2013; Hussein and Suttie 2016).

\subsection{Growing relevance of Water-Energy-Food (WEF) Nexus thinking}

In the backdrop of expanding urban boundaries and growing population, the need for strengthening urban-rural linkages is increasingly being realized as urban areas largely meet their WEF resource demands from outside their physical boundaries (Heard et al. 2017; Romero-Lankao et al. 2017). Amidst the already existing shortfalls in meeting WEF resource demands (as detailed by Stephan et al. 2018), the World Economic Forum has for long underlined that food crisis, energy shocks and water scarcity are projected to be some of the major risks to contemporary world (WEF 2018). These concerns become even more serious as WEF sectors are closely linked in form of a nexus (eg. both water and energy essential for food production), and the demands for all of them are set to increase (Mohtar and Daher 2012). The notion of WEF nexus thinking has existed for a long time. However, it was officially recognized only after the Bonn 2011 Nexus Conference (Hoff 2011). WEF nexus has also gained increasing importance for policymakers in relation to the Post-2015 development agenda (Bizikova et al. 2013; Biggs et al. 2015; Jones et al. 2017). Today, it is widely recognized that failing to recognize the cross-sectoral interdependencies of WEF sectors will lead to unintended consequences to the overall system. As such, WEF nexus thinking has become a pre-requisite for enhancing resource efficiency and achieving sustainable development at transboundary scale (Schlör et al. 2018; Djehdian et al. 2019). Particularly for large developing countries like India with high population density, the WEF nexus thinking is increasingly important, as they are highly water stressed (Pandey 2019).

To date, considerable scientific advances have been made in WEF nexus research. Various research frameworks, models and multi-disciplinary approaches have been established for analyzing WEF systems (Bizikova et al. 2013; Mohtar and Lawford 2016). However, their applicability at policy and governance levels continues to be restrained as most of the existing frameworks do not incorporate spatial and temporal scales (Endo et al. 2015). The transboundary WEF resource linkages are seldom considered in development planning, as majority of the policy decisions concerning the WEF sectors are made by separate institutions, with a sectoral approach (Pittock et al. 2013; Leck et al. 2015). A genuine need for spatially visualizing the WEF linkages has been realized, in addition to producing grounded evidence for policy making at local level. 


\subsection{Knowledge-based approach for development planning}

'Knowledge' has wide-ranging definitions, but it is commonly related to a fluid mix of framed experiences, values, contextual information (Liyanage et al. 2009). The importance of a knowledge-based approach for development planning has been recognized for a long time (Knight 1995). Emphasizing on using knowledge as a strategic resource, recent studies (eg. Yigitcanlar 2010a) have stressed for a knowledge-based development approach to cities and regions. The knowledge-based development approach mainly builds on knowledge (technical, financial, market etc.) as the central structuring element for developing urban areas and wider regions (Yigitcanlar 2010b; Lonnqvist et al. 2014). Although the key purpose of knowledgebased development are economic prosperity and human development (Laszlo and Laszlo 2007), it also focuses on environmental and social aspects for sustainable development of territories (Chang et al. 2018).

Recently, there have been several emerging perspectives for knowledge management ranging from knowledge-based economy to knowledge-based societies. Although these concepts are not firmly defined yet, the 'knowledge-based' attribute mainly aims to prioritize the intangible values or intellectual assets, rather than material and monetary (tangible) assets (Carrillo 2015). While information technology forms the basis of knowledge management, knowledge-based approach gives particular attention to local, historical, and ecological values, that affect the quality of life in cities and regions (Knight 1995). Various theoretical frameworks have recently been discussed for the application of knowledge-based approach to specific areas like disaster management (eg. Arain 2015) and urban development (eg. Yigitcanlar and Lönnqvist 2013). Through these studies, the wide-ranging importance of knowledge-based frameworks in terms of facilitating well-informed decisions, risk assessment, swift disaster response, improved coordination etc. have been recognized. Building on the contextual strengths and values, researchers have emphasized on applying knowledge and information into all research and development activities at local level.

\section{CASE STUDY AREA OF NAGPUR METROPOLITAN AREA (NMA), INDIA}

Nagpur, often called the heart of India, is at the geographical center of the country (location map shown in Figure 1). The strategic central location and good connectivity from all parts of the country enables it to be the logistical hub of India. It lies on the Deccan plateau at an altitude of 310 meters above sea level. Spread over 217 square kilometers area (sq.km.), Nagpur is the third largest city and the winter capital of the Indian state of Maharashtra. It is also a major commercial and political center of the Vidarbha region of Maharashtra. Nagpur Metropolitan Area (NMA), that includes 721 villages and 24 Census towns, is spread across an area of 3,567 sq.km. (NMC 2011; NIT 2015). As per Census 2011, the population of Nagpur city is 2.405 million and the population of NMA is 1.037 million (predominantly rural). Within the boundary of NMA, Nagpur Smart City and Wadoda 'Rurban' Cluster are presently been 
developed under two different missions of Government of India, as also explained in Section 1. The following sub-sections discuss about their actions plans, key strengths and shortcomings.

\subsection{Nagpur Smart City}

Nagpur is presently been developed as one of the 100 smart cities under the 'Smart Cities Mission' launched by Government of India in 2015 (SCM 2015). Under the SCM, Nagpur city aims to transform itself into a well-planned, Eco-friendly, Edu-city that Electronically connects governments, businesses, people and spaces seamlessly to co-create a clean, green, safe, prosperous, healthy and Inclusive ecosystem. As per its action plan (smart city proposal), 'Area-based interventions' are proposed in 951 acres (3.84 sq.km.) of land on the eastern border of Nagpur city wherein retrofitting will be undertaken through the town planning scheme to deliver smart physical and social infrastructure and introduce mixed-use allocations to increase commercial and economic activity. In addition to that, the 'Pan-city initiatives' under SCM include solid waste management and transportation monitoring through CCTV-monitored central command system (Nagpur SCP 2016).

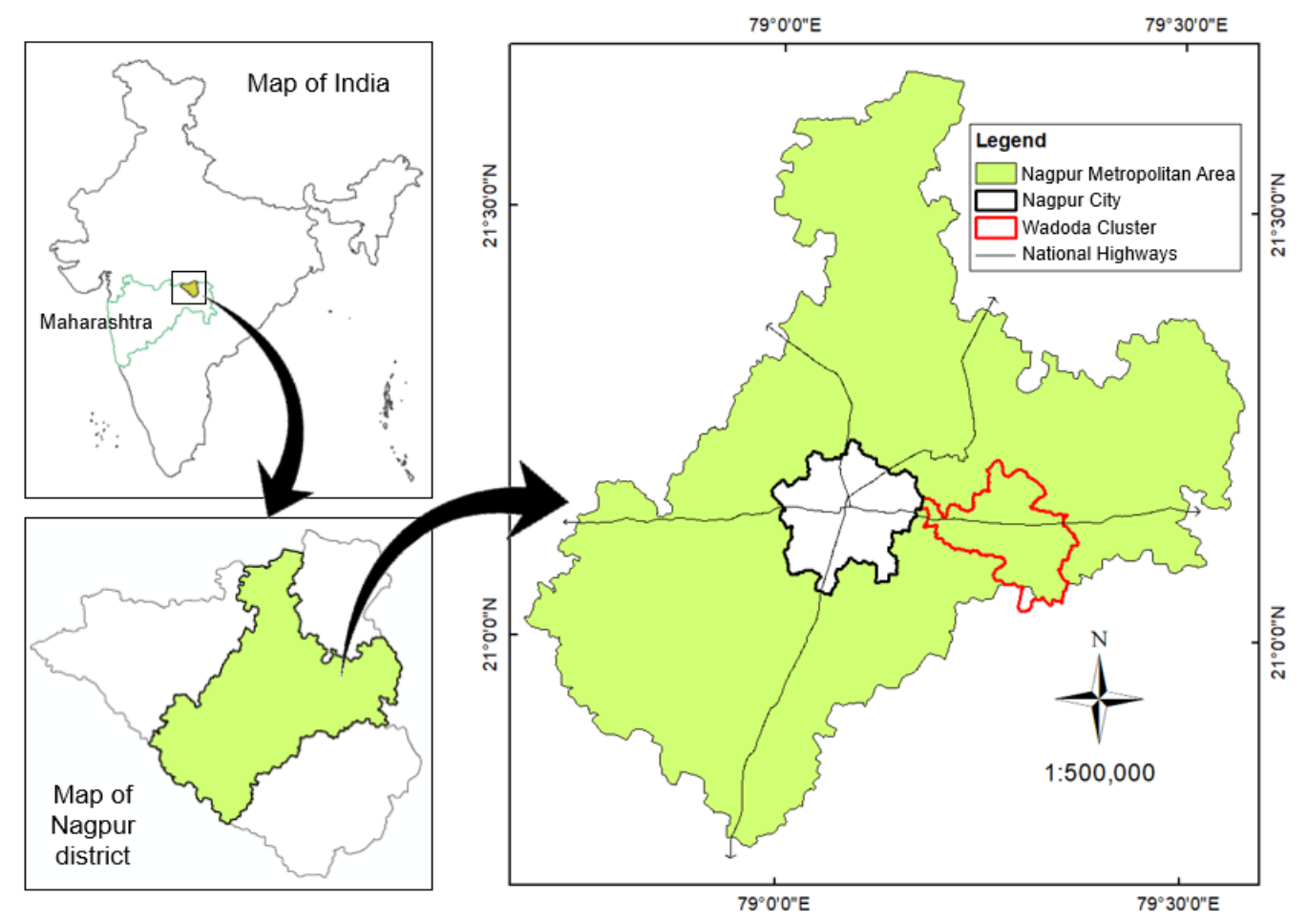

Figure 1. Location map of Nagpur Smart City and Wadoda Rurban Cluster in NMA (Author)

\subsection{Wadoda Rurban Cluster}

After a rigorous screening process, Wadoda Cluster from Nagpur district has been selected as one of the 300 Rurban Clusters being developed across India, under the 'National Rurban 
mission' (NRuM) launched by Government of India in 2016 (NRuM 2016). Under this mission, a Rurban cluster is defined as a group of geographically contiguous villages. Based on 14 desirable components (shown in Table 1), NRuM aims to promote local economic development, enhance basic services and create well planned clusters.

Wadoda 'Rurban' cluster comprises of a total of 31 villages falling under 19 Gram Panchayats (village councils) and having a total population of 38,679 . In lines to the objectives set by $\mathrm{NRuM}$, the vision of Wadoda cluster is to retain the dominant agrarian culture besides borrowing urban features such as water supply, drainage, sanitation, and better road network. Accordingly, the cluster is being developed for agro-tourism, agro-service and processing, ecluster and digital cluster, along with striving to fulfill 100 percent requirement of water supply, sanitation, road-drainage, and solid waste management (Wadoda ICAP 2017).

Table 1. Key components in action plans of Nagpur Smart City and Wadoda Rurban Cluster (Source: Nagpur SCP 2016; Wadoda ICAP 2017)

\begin{tabular}{|l|l|}
\hline \multicolumn{1}{|c|}{ Nagpur Smart City } & \multicolumn{1}{c|}{ Wadoda Rurban Cluster } \\
\hline 1. Carbon Neutral \& Sustainable Habitat & 1. Skill Development training \\
2. Swachh Nagpur & 2. Agri-services and Processing \\
3. Urban Greens & 3. Digital Literacy \\
4. Inclusive Living & 4. 24x7 Piped Water Supply \\
5. Poly-centric City & 5. Sanitation \\
6. Safe \& Walkable Streets & 6. Waste Management \\
7. Economic Vitality & 7. Access to Village Streets \\
8. Transit Oriented Development & 8. Village Street Lights \\
9. Connect Places \& Move People & 9. Health \\
10. Walk-to-Work principles & 10. Up gradation of schools \\
11. Digital \& Transparent Governance & 11. Inter village Road connectivity \\
12. Boost job creation & 12. Citizen Service Centres \\
& 13. Public transport \\
& 14. LPG Gas Connections \\
\hline
\end{tabular}

Table 1 highlights the key components specified in the action plans of Nagpur Smart City and Wadoda Rurban cluster. While Nagpur smart city is focusing on socio-economic wellbeing and good governance through components of 'Smart Environment', 'Smart Living', 'Smart Mobility' and 'Smart Governance', the Wadoda Rurban cluster is imprecisely building on similar components for stimulating local economic development and bettering public services. Notably, both the smart developments are focused on place-based goals and there is no 
significant consideration to transboundary urban-rural linkages like water and food supply etc. It is also important to note that both the discrete developments are emphasizing on uninterrupted water and energy supply, however, their focus is more on localized infrastructure development rather than transboundary source conservation.

\section{RESEARCH METHODOLOGY}

Based on literature review, this study works towards developing a knowledge-based conceptual framework for understanding the flow of water resources within NMA from a WEF nexus perspective. To achieve that, the authors first establish a simplistic understanding of the complex flow of WEF resources between urban and rural areas in NMA. The key agencies managing the flow of WEF resources are also underlined to establish a thorough understanding of governance structures. The linear flow of these resources within NMA is understood based on existing literature, policy documents and media reports. Thereafter, for understanding the overall flow of water resources in NMA from a wider historical perspective, the authors studied the Performance Evaluation Study report of Pench Irrigation Project (key freshwater source of NMA) by Central Water Commission (CWC 2001). This report is an official document, which the authors collected from the office of Pench Irrigation Project at the State Irrigation Department in Nagpur. Based on this study, the authors discussed the key source areas for Nagpur city, key dependent sectors (including urban, industrial and agriculture), and the wastewater generated from the Nagpur city. With a precise understanding of the flow of water resources for WEF related sectors in NMA, the knowledge-based conceptual framework is developed in consideration to the cross-sectoral linkages between these sectors. Supported with relevant statistical information derived from the policy documents, the framework also explains the overall flow of water resources (both freshwater and wastewater) in NMA, in reference to Nagpur Smart City and Wadoda Rurban cluster. Based on the key findings derived from the developed framework, feasible measures are then suggested to link the upcoming smart urbanrural developments in NMA.

\section{WATER-ENERGY-FOOD RESOURCE SUPPLY IN NMA}

\subsection{Water Supply}

Water demands within NMA are met through surface and groundwater sources. While water for urban areas is mainly sourced from surface water sources like lakes, rivers and reservoirs, the rural areas are mainly dependent on groundwater sources. Pench reservoir located in Northern part of NMA (highlighted in Figure 2) is the main source of drinking water for Nagpur city as it caters to more than 70 percent of city's water demands. Through canal and pipeline network, water from Pench reservoir is brought to the treatment plants located at Gorewada and the treated water is then supplied to the residents of Nagpur city. The city's water supply is currently managed by Nagpur Municipal Corporation ' $\mathrm{NMC}$ ' in collaboration with a private 
agency named Orange City Water Pvt. Ltd. under a 'Public Private Partnership' (PPP) agreement. For the rural areas, the water supply is managed by multiple agencies including Zilla Parishad, the Maharashtra Jeevan Pradhikaran and the Groundwater Survey and Development Agency (NMC 2011; NIT 2015).

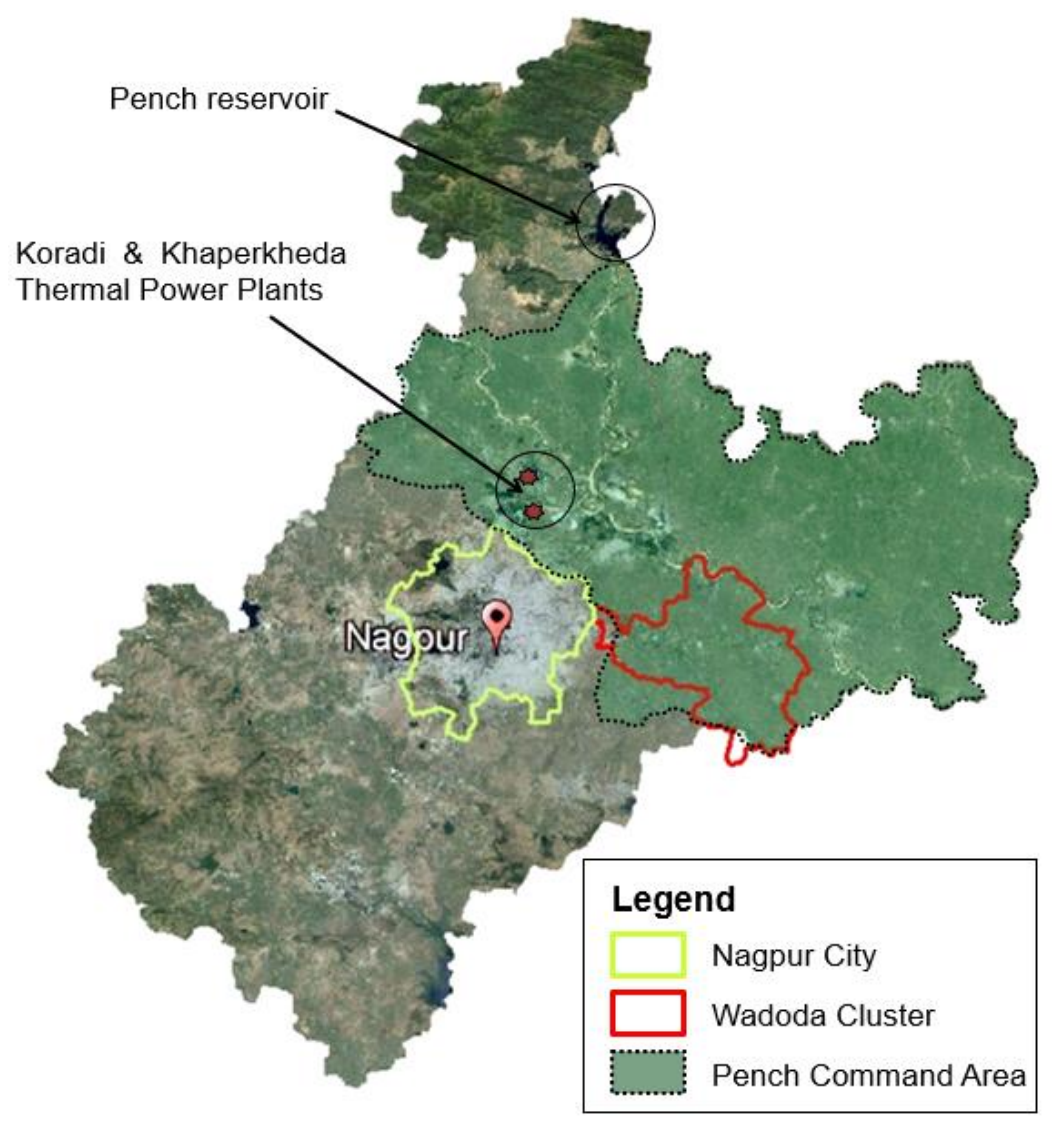

Figure 2. Google earth imagery of NMA (raster image sourced from USGS (2019)) Pench command area only within NMA boundary is shown, but it also extends outside NMA

As per MPCB (2019), the city presently generates around 505 Million Litres/Day 'MLD' wastewater, of which around 130 MLD is being treated at Bhandewadi sewage treatment plant (Roy 2018). In lines with the joint agreement between NMC and Maharashtra State Power Generation Co. Ltd. 'MAHAGENCO', the treated wastewater is supplied to the Koradi Thermal Power Station 'TPS' for reuse. The residual untreated wastewater is directly released in the natural drains which pollutes the streams and rivers (mainly Nag river) flowing through the city towards downstream areas through Wadoda Rurban Cluster.

\subsection{Energy Supply}

Nagpur region has a very prominent power sector as two important TPSs namely Koradi and Khaparkheda TPS (having total capacity of 3,740 Megawatt) are located near Nagpur city 
(location highlighted in Figure 2) and operated by MAHAGENCO (Roy 2019). Although, the region is connected through the National Grid, it is important to note that Nagpur region contributes to around 47 percent of the Maharashtra state's power (UrbanEmissions.info 2019). Generation, transmission and distribution of electricity is divided between three agencies namely Maharashtra State Electricity Distribution Co. Ltd. 'MSEDCL' for power distribution, MAHAGENCO for power generation and Maharashtra State Electricity Transmission Co. Ltd. 'MAHATRANSCO', for power transmission (NIT 2015).

\subsection{Food supply}

NMA is predominantly an agricultural area. Around 71 percent of total geographical area of Nagpur is cultivable and crops are grown on 79 percent area of total cultivable area (NIT 2015). A bulk of these agricultural lands, as highlighted in Figure 2, fall under the command area of Pench Irrigation Project. Although there is no established database of the food source areas in NMA, much of Nagpur city's food demand is met through the food grown in surrounding villages including those in Wadoda Rurban cluster (Kulkarni 2019). The food produced in these villages is mainly brought to the Kalamna wholesale market in Nagpur city by farmers, traders, agents etc. wherein it is taxed before been sold to the retail traders. The food supply in Kalamna market yard is managed by the Agricultural Produce and Marketing Committee 'APMC', a marketing board established by the state government (APMC 2019).

\section{KNOWLEDGE-BASED CONCEPTUAL FRAMEWORK}

In reference to Yigitcanlar and Lönnqvist (2013), a knowledge-based conceptual framework has been developed for the case of NMA that recognizes the cross-sectoral interdependencies between urban and rural areas, particularly for the networks of freshwater and wastewater resource for WEF sectors (Figure 3). It has been developed with a precise understanding of the spatial settings related to the key water sources, human settlements, and the wastewater flow. Deriving information from key policy documents, the framework also highlights the relevant statistical information related to storage capacities of reservoirs and allocated quantities of water for different purposes. 


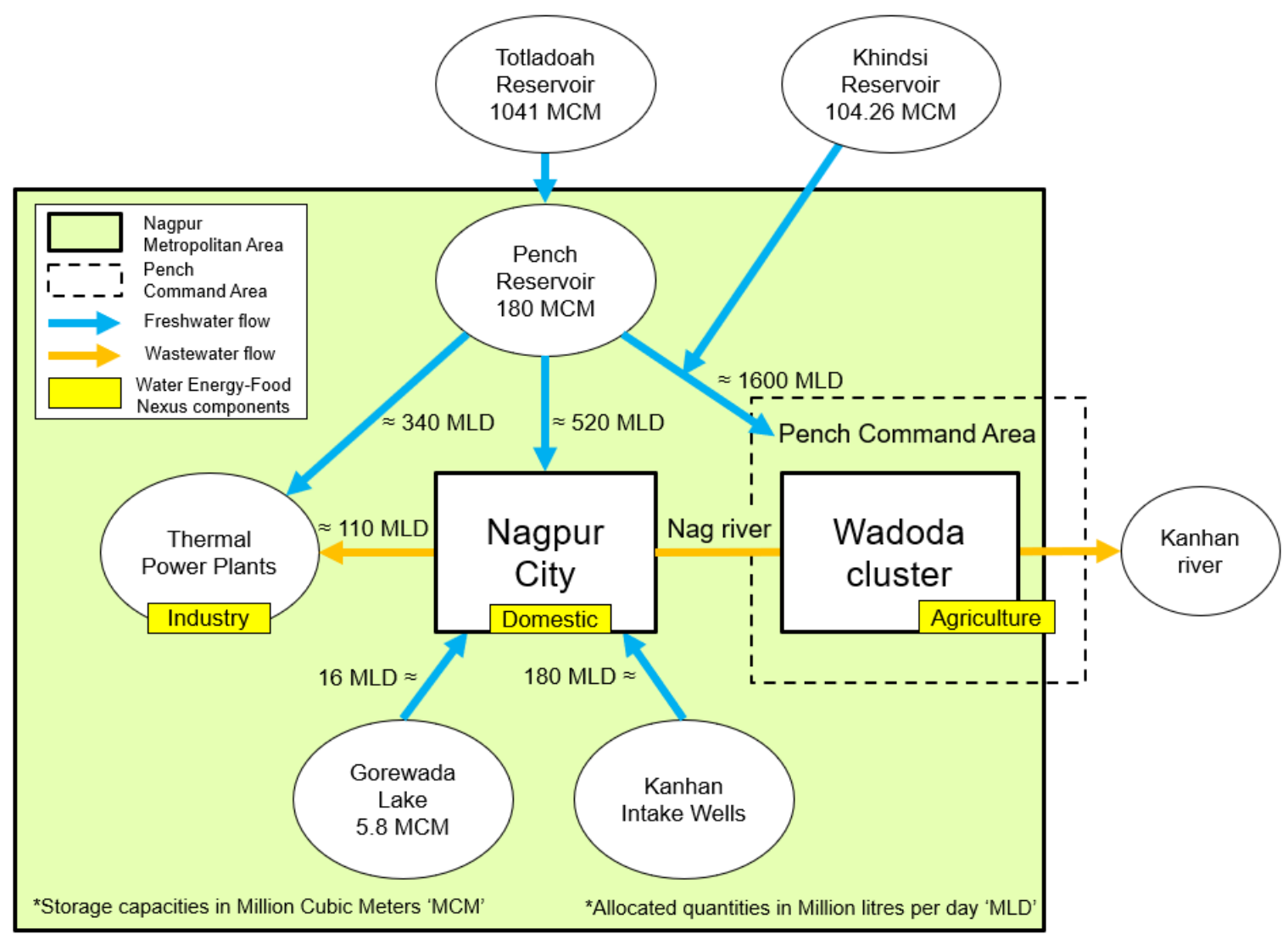

Figure 3. Knowledge-based Conceptual framework of water resource flow in NMA

As explained in Figure 3, Nagpur city presently receives bulk of its water supply from three key surface water resources namely Pench reservoir, Gorewada lake and Kanhan Intake wells (statistical data sourced from NIT 2015). Among these sources, the key freshwater source of 'Pench reservoir' is one of the three reservoirs under the Pench Irrigation Project 'PIP' (other two are Totladoah and Khindsi). As per the water allocation planning for the PIP (CWC 2001), it serves for several other purposes including energy production (for Koradi and Khaperkheda TPSs) and irrigation in around 104476 hectares of fertile land in North-Eastern apart of NMA (MWRRA 2017), including all the villages in Wadoda Rurban cluster. In this manner, the PIP serves as a one key water source for urban domestic needs, agriculture and industries (TPSs) in NMA context.

Further to that, the treated wastewater from the city is also supplied to the TPSs for reuse in energy production. And, the untreated wastewater generated from the city flows through natural streams (Nag river) towards the downstream rural areas, where it serves for irrigation purposes (Mudholkar 2018). Since the supply of fresh food in Nagpur city considerably depends on the food grown in surrounding rural areas, the degrading water quality in these natural streams may also raise nexus-based concern for food quality in the city and the wider region. Moreover, the readers should note that this framework only provides a precise understanding of the water resource flow network. However, there are several other intermediary phases involved in the flow of these resources between urban and rural areas (like water treatment plants), that are discretely managed at various governance levels. 


\section{DISCUSSION}

The developed knowledge-based conceptual framework, from the lens of water resource flow, helps in visualizing the nexus-based interdependencies between the WEF sectors in NMA. While PIP serves as a key water source for various purposes in NMA, it is important to understand that the project itself receives water from the upstream areas in the neighboring state of Madhya Pradesh. It is therefore highly important to address the WEF nexus issues in Nagpur at a transboundary scale. Specifically, because Nagpur has recently witnessed high climate variations in form of extreme cold, heatwaves and fluctuating rainfall patterns (Behl 2019). It has also experienced severe water stress situation due to the declining surface and groundwater availability (Dhyani et al. 2018; Deshkar 2019). As such, regional level planning exercises in reference to the developed knowledge-based framework will be critical to ensure sustainable development. While 'SCM' and 'NRuM' are meant to build ideal models that can be replicated widely for catalyzing the creation of similar smart urban-rural developments in various parts of India, the adjacent development of Smart city and Rurban cluster in NMA provides a genuine opportunity to infuse the idea of coordinated urban-rural development. Although, there is no single definition of smart developments, the study emphasizes that safeguarding the flow of key resources like water, energy, food etc. between urban and rural areas should be given due importance in the wake of emerging disaster risks like COVID-19. The cutting edge ICT features of smart developments in urban and rural areas should be duly utilized to develop smart urban-rural linkages in Nagpur region. To achieve that, the study suggests three specific focal points as follows.

\subsection{Enhancing data collection at urban-rural interface}

Smart developments build on ICT features and knowledge management. As such, data collection and management will play an important role in making any city or village smart. Based on the developed knowledge-based framework for resource flow in NMA (Figure 3), the upcoming smart developments should adopt strategies to enhance data collection at specific nodes of mutual concern. As explained through the knowledge-based framework, the flow of defined resources between urban and rural areas encompasses several intermediate phases. To ensure smart and effective flow of resources from source areas to consumers, there is need for improved data collection at different stages of flow across various scales. Table 2 presents few of the key focal points for data collection that could be taken into consideration for enhancing resource efficiency by the upcoming smart developments in NMA.

\subsection{Enhancing sectoral and administrative coordination}

Based on the developed framework (Figure 3), the resource elements of water, energy, and food are evident to be closely linked. Against the growing population, rapid urbanization trends and changing climate, there is a genuine need for integrated development planning at the urbanrural interface. While the stock of natural resources is limited, there is a need to find better 
ways for collective resource management through transboundary cooperation. Presently, there are several departments and agencies at various territorial levels that discretely manage the flow of WEF resources between urban and rural areas in NMA (also explained in Section 5). However, there is a genuine need for enhancing the sectoral and administration coordination to ensure knowledge sharing for the success of smart developments. Partnerships and coordination between concerned departments can facilitate timely and informed decision making at the regional level.

Table 2. Potential areas of data collection to enhance coordinated urban-rural development

\begin{tabular}{|c|c|}
\hline Sector & Exploratory research questions \\
\hline \multirow{2}{*}{ Food } & What are the key source areas of food (fruits, vegetables etc.) for Nagpur city? \\
\hline & $\begin{array}{l}\text { What are the consumer preferences for food products? What type of food products } \\
\text { are grown in Wadoda Rurban cluster? }\end{array}$ \\
\hline \multirow[b]{2}{*}{ Energy } & What is the overall energy demand for food production and water supply? \\
\hline & $\begin{array}{l}\text { What are the negative implications of energy waste (fly ash etc.) on groundwater } \\
\text { resources and food production? }\end{array}$ \\
\hline \multirow{2}{*}{ Water } & What are the key water-related risks (floods, drought etc.) in Wadoda Cluster? \\
\hline & $\begin{array}{l}\text { What is the impact of Nagpur city's untreated wastewater flowing through Nag } \\
\text { river on food production in Wadoda cluster? }\end{array}$ \\
\hline
\end{tabular}

\subsection{Need for urban-rural collaboration and partnerships}

In contrast to the dichotomous development planning of upcoming smart developments, there is a need for holistic and territorial-based approaches to leverage their interlinkages and promote policy coherence. While the smart developments in NMA are currently being built with focus on specific dimensions like 'Smart Mobility', 'Smart Environment', 'Smart People' etc., it is also important to consider the other mutually important components like 'Food Supply', 'Wastewater Management' and 'Integrated Governance'. The importance of continued food supply chains and integrated governance at regional level, has also been globally recognized under the ongoing COVID-19 pandemic outbreak (gFSC 2020). Focus on these aspects will also encourage urban-rural collaboration and partnerships between different stakeholders at various governance levels, in lines with the objectives of Sendai Framework for Disaster Risk Reduction 2015-2030 (UNDRR 2015). 


\section{CONCLUSIONS}

This study presents a knowledge-based conceptual framework that visualizes the flow of water resources in Nagpur region, from WEF nexus perspective. It has been highlighted that the resource flow between urban and rural areas encompasses a wide range of actors, across different sectors and administrative scales. While urban and rural areas in NMA are discretely governed, the study emphasizes on developing integrated platforms for natural resource management at regional level. This is in lines with the global policy frameworks of SDGs, The New Urban Agenda and SFDRR, that have emphasized on transboundary cooperation and multi-sectoral approaches to resource management. It is therefore hoped that this study will build the awareness of policy makers and assist for evidence-based policymaking in Nagpur region. It will also serve as an important basis for the integrated development planning of Smart Cities and Rurban clusters in India. While the concept of WEF nexus has recently gained increasing attention in policy making, this study would help to visualize the WEF linkages between urban and rural areas at regional scale. It will also provide a new perspective to researchers, academicians, policy makers etc. in context of urban-rural coordinated development. Moreover, the research contributes to linking the existing body of literature on urban-rural linkages, smart developments and WEF nexus.

The authors acknowledge three specific limitations to this research as follows, 1) The knowledge-based conceptual framework developed in this study only considered the linear flow of freshwater into Nagpur city and the wastewater outflows. However, further research needs to be conducted in consideration to groundwater utilization as well as other surface water sources (like lakes, ponds) within NMA; 2) The developed knowledge-based framework also poses limitations in precisely understanding the nexus-based linkages between the components of water, energy and food systems, which are mutually exclusive and yet interdependent. There is a need for further investigating and cross-validating these linkages by applying more scientific approaches, in consideration to other urban-rural linkage components like flow of goods, people etc.; 3) The developed framework is case specific and it may not be applicable in other contexts. The future scope of the study includes addressing these limitations as well as focusing on other ways of connecting smart urban and rural developments.

\section{ACKNOWLEDGEMENTS}

The authors sincerely acknowledge the valuable support received from the office of Pench Irrigation Project (PIP) at State Irrigation Department, Government of Maharashtra, Nagpur, in conducting this study. The first author (V.S.) is also thankful to the Ministry of Education, Culture, Sports, Science and Technology (MEXT), Japan for the provided scholarship.

This research was supported by the Japan Society for the Promotion of Science (JSPS) and the Indian Council of Social Science Research (ICSSR) under the India-Japan Bilateral Research Project. The authors are also thankful to the Taikichiro Mori Memorial Research Grant for supporting the Overseas Academic Conference Presentation. 


\section{REFERENCES}

Akkoyunlu, S. (2015) The Potential of Rural-Urban Linkages for Sustainable Development and Trade. International Journal of Sustainable Development \& World Policy, Conscientia Beam, 4(2): 20-40. DOI: 10.18488/journal.26/2015.4.2/26.2.20.40

APMC (2019) Agricultural Produce Market Committee, Nagpur. Available online: https://www.apmcnagpur.com/english/aboutus.html (Accessed on 22nd February 2020)

Arain, F. (2015) Knowledge-based Approach for Sustainable Disaster Management: Empowering Emergency Response Management Team. Procedia Engineering, 118: 232239. https://doi.org/10.1016/j.proeng.2015.08.422

Bari, R. and Munir, A. (2014) Spatial Analysis of Rural-Urban Linkages in Basti District (U.P.). IOSR Journal of Humanities and Social Science, 19 (4): 127-133. DOI: 10.9790/08371944127133

Behl, M. (2019) Climate change impacting city weather too: Expert. The Times of India. Avai lable online: https://timesofindia.indiatimes.com/city/nagpur/climate-change-impacting-cit y-weather-too-expert/articleshow/68209049.cms (Accessed on 24th February 2020)

Biggs, E. M., Bruce, E., Boruff, B., Duncan, J.M.A., Horsley, J., Pauli, N., McNeill, K. et al. (2015) Sustainable Development and the Water-Energy-Food Nexus: A Perspective on Livelihoods. Environmental Science \& Policy, 54: 389-97.

https://doi.org/10.1016/j.envsci.2015.08.002

Bizikova, L., Roy, D., Swanson, D., Venema, H.D. and McCandless, M. (2013) The WaterEnergy-Food Security Nexus: Towards a Practical Planning and Decision-Support Framework for Landscape Investment and Risk Management. IISD Report, International Institute for Sustainable Development (IISD), Winnipeg, Canada.

Blais, P. (2003) Smart Development for Smart Growth, Issue Paper No.6. Neptis Foundation. Toronto, Ontario. https://www.neptis.org/sites/default/files/smart_growth_issue_papers_smart_development_ and_smart_growth/sm_dev_nip6_report.pdf

Carrillo, F.J. (2015) Knowledge-based development as a new economic culture. Journal of Open Innovation: Technology, Market, and Complexity, 1, 15: 1-17. https://doi.org/10.1186/s40852-015-0017-5

Chang, D.L, Sabatini-Marques, J., da Costa, E.M., Selig, P.M. and Yigitcanlar, T. (2018) Knowledge-based, smart and sustainable cities: a provocation for a conceptual framework. Journal of Open Innovation: Technology, Market, and Complexity, 4(5); 1-17. https://doi.org/10.1186/s40852-018-0087-2

Chichernea, V. (2015) Smart Cities Communities and Smart ICT Platform. Journal of Information Systems \& Operations Management 9 (1): 1-11. 
CWC (2001) Performance Evaluation Study of Pench Irrigation Project, Maharashtra, Central Water Commission (CWC) Monitoring Central Unit Appraisal Directorate, Nagpur.

Deshkar, S. (2019) Resilience Perspective for Planning Urban Water Infrastructures: A Case of Nagpur City. In Urban Drought: Emerging Water Challenges in Asia; Ray, B., Shaw, R. Eds.; Springer Nature Singapore Pte Ltd.: Singapore, 2019; pp. 131-154. https://doi.org/10.1007/978-981-10-8947-3

Dhyani, S., Lahoti, S., Khare, S., Pujari, P., Verma, P. (2018) Ecosystem based Disaster Risk Reduction approaches (EbDRR) as a prerequisite for inclusive urban transformation of Nagpur City, India. International Journal of Disaster Risk Reduction, 32: 95-105. https://doi.org/10.1016/j.ijdrr.2018.01.018

Djehdian, L.A., Chini, C.M., Marston, L., Konar, M. and Stillwell, A.S. (2019) Exposure of urban food-energy-water (FEW) systems to water scarcity. Sustainable Cities and Society, 50. https://doi.org/10.1016/j.scs.2019.101621

Douglass, M. (1998) A regional network strategy for reciprocal rural-urban linkages: An agenda for policy research with reference to Indonesia. Third World Planning Review, 20 (1): 1-35. https://doi.org/10.3828/twpr.20.1.f2827602h503k5j6

Egal, F. and Forster, T. (2020) Urban-Rural Linkages in the time of COVID-19. Urban-Rural Linkages (URL) NewsLetter, 2: 6-7. http://urbanpolicyplatform.org/wp-content/uploads/20 20/05/URL-NewsLetter_Issue2_Web.pdf

Endo, A., Burnett, K., Orencio, P.M., Kumazawa, T., Wada, C.A., Ishii, A., Tsurita, I.; Taniguchi, M. (2015) Methods of the Water-Energy-Food Nexus. Water, 7(10): 5806-5830. https://doi.org/10.3390/w7105806

Garcia, B. (2007) Working and learning in a knowledge city: a multilevel development framework for knowledge workers. Journal of Knowledge Management, 11 (5): 18-30. https://doi.org/10.1108/13673270710819771

gFSC (2020) Coronavirus, Impact on Well-Being, Health, Food Access and Food Security. global Food Security Cluster (gFSC), Rome, Italy.

https://fscluster.org/sites/default/files/documents/covid_19_impact_on_food_security.pdf

Heard, B.R., Miller, S.A., Liang, S. and Xu, M. (2017) Emerging challenges and opportunities for the food-energy-water nexus in urban systems. Current Opinion in Chemical Engineering, 17: 48-53. http://dx.doi.org/10.1016/j.coche.2017.06.006

Hoff, H. (2011) Understanding the Nexus. Background Paper for the Bonn2011 Conference: The Water, Energy and Food Security Nexus. Stockholm Environment Institute, Stockholm.

Holt, R. (2018). Global Cities, Which cities will be leading the global economy in 2035 ?

Oxford Economics. Available online: https://workplaceinsight.net/wpcontent/uploads/2018/12/Global-Cities-Dec-2018.pdf (Accessed on 22nd February 2020) 
Hui, R. and Wescoat, J.L. (2019) Visualizing peri-urban and rurban water conditions in Pune district, Maharashtra, India. Geoforum,102: 255-266.

https://doi.org/10.1016/j.geoforum.2018.01.008

Hussein, K. and Suttie, D. (2016) Rural-urban linkages and food systems in Sub-Saharan Africa, The Rural Dimension. International Fund for Agricultural Development (IFAD), Rome, Italy. https://ageconsearch.umn.edu/record/280043? ln=en (accessed on 22nd February 2020)

Jones, K., Magliocca, N.R. and Hondula, K. (2017) White Paper: An Overview of Conceptual Frameworks, Analytical Approaches and Research Questions in the Food-Energy-Water Nexus. National Socio-Environmental Synthesis Center (SESYNC), University of Maryland. https://doi.org/10.13016/M2BK10

Kim, S.M. (2015) An Empirical Analysis on Urban-Rural Linkage in Mumbai Metropolitan Area. The Journal of Development Practice, 2: 20-25.

http://journals.dbuniversity.ac.in/ojs/index.php/jdp/article/view/85

Knight, R.V. (1995) Knowledge-based Development: Policy and Planning Implications for Cities. Urban Studies, 32(2): 225-260. https://doi.org/10.1080/00420989550013068

Komninos, N. (2011) Intelligent cities: Variable geometries of spatial intelligence. Intelligent Buildings International, 3 (3): 172-188. https://doi.org/10.1080/17508975.2011.579339

Kulkarni, M. (2019) Role of Urban-Rural linkages in Achieving Resilience. Unpublished Master Thesis, Department of Architecture and Planning, Visvesvaraya National Institute of Technology, Nagpur, India.

Kumar, T.M.V. and Dahiya B. (2017) Smart Economy in Smart Cities. In: Vinod Kumar T. (eds) Smart Economy in Smart Cities. Advances in 21st Century Human Settlements. Springer, Singapore. https://doi.org/10.1007/978-981-10-1610-3_1

Laszlo, K.C. and Laszlo, A. (2007) Fostering a Sustainable Learning Society through Knowledge Based Development. Systems Research and Behavioral Science, 24(5): 493-503. https://doi.org/10.1002/sres.850

Leck, H., Conway, D., Bradshaw, M. and Rees, J. (2015) Tracing the Water Energy Food Nexus: Description, Theory and Practice. Geography Compass 9(8): 445-460. https://doi.org/10.1111/gec3.12222

Liyanage, C., Elhag, T., Ballal, T. and Li, Q. (2009) Knowledge communication and translation- A knowledge transfer model. Journal of Knowledge Management, 13(3): 118131. https://doi.org/10.1108/13673270910962914

Lonnqvist, A., Kapyla, J., Salonius, H. and Yigitcanlar, T. (2014) Knowledge that matters: Identifying regional knowledge assets of the Tampere region. European Planning Studies, 22(10): 2011-2029. https://doi.org/10.1080/09654313.2013.814621 
Meijer, A. and Bolívar, M.P.R. (2013) Governing the Smart City: Scaling-Up the Search for Socio-Techno Synergy. Proceedings of 2013 EGPA Annual Conference, Edinburgh, United Kingdom, September 11-13. https://www.scss.tcd.ie/disciplines/information_systems/egpa/docs/2013/BolivarMeijer.pdf

Mohtar, R.H. and Daher, B. (2012) Water, Energy, and Food: The Ultimate Nexus. Chapter in Encyclopedia of agricultural, food, and biological engineering, 2nd ed; Heldman, D., Moraru, C. Eds.; CRC Press: Boca Raton. DOI: 10.1081/E-EAFE2-120048376

Mohtar, R.H. and Lawford R. (2016) Present and future of the water-energy-food nexus and the role of the community of practice. Journal of Environmental Studies and Sciences, 6:192-199. https://doi.org/10.1007/s13412-016-0378-5

Mora, L., Bolici, R. and Deakin, M. (2017) The First Two Decades of Smart-City Research: A Bibliometric Analysis. Journal of Urban Technology, 24(1): 3-27. https://doi.org/10.1080/10630732.2017.1285123

Morton, J., Solecki, W., Dasgupta., Dodman, David and Rivera-Ferre, Marta G. (2014) Crosschapter box on urban-rural interactions - context for climate change vulnerability, impacts, and adaptation. In: Field, C. and Barros, V., (eds.) Climate Change 2014: Impacts, Adaptation, and Vulnerability. Cambridge University Press, Cambridge and New York, pp. 153-155.

MPCB (2019) Note on Domestic Wastewater Reuse Project at Nagpur, Nagpur Municipal Corporation to Supply Water For (3x660 Mw) Koradi Thermal Power Plant. Maharashtra Pollution Control Board (MPCB), Nagpur.

http://www.mpcb.gov.in/sites/default/files/focus-area-reportsdocuments/NMC_\%26_KTPS_success_story_28052019.pdf

Mudholkar, P.P. (2018) Impact of Urbanization on River and Its Surrounding Structures: Case of Nag River Nagpur. International Journal of Science and Research (IJSR), 7(8): 520-538. DOI: $10.21275 /$ ART2019530

MWRRA (2017) Petition filed by Adv Ashish Jaiswal at Nagpur bench of Honorable High Court of Bombay as regards Making Provision for Irrigation Purpose by Curtailing the Use of Water from Pench Project Complex by Nagpur Municipal Corporation- Case No 8 of 2017, Maharashtra Water Resources Regulatory Authority (MWRRA). https://mwrra.org/wp-content/uploads/2018/11/Case-No-8-of-2017-Final-Order.pdf

Nagpur SCP (2016) The Smart City Challenge Stage 2: Smart City Proposal Nagpur. Ministry of Urban Development, Government of India. https://smartnet.niua.org/sites/default/files/r esources/Nagpur_SCP.pdf

NIT (2015) Nagpur Metropolitan Area Development Plan 2012-2032, Draft Development Plan Report. Nagpur Improvement Trust (NIT). http://www.nitnagpur.org/pdf/Metro_Region_DP.pdf 
NMC (2011) Draft City Sanitation Plan, Nagpur Municipal Corporation (NMC), Nagpur, Maharashtra.

NRuM (2016) Shyama Prasad Mukherji Rurban Mission-National Rurban Mission (NRuM). Ministry of Rural Development, Government of India. Available online: http://rurban.gov.in/ (Accessed on 22nd February 2020)

Pandey, K. (2019) India world's 13th most water-stressed country: WRI. Down to Earth (DTE). Available online: https://www.downtoearth.org.in/news/water/india-world-s-13th-mostwater-stressed-country-wri-66066 (Accessed on 30th May 2020)

Peeters, A. and Marinho, E. (2008) Urban-Rural Interactions: Spatial Organization and Explaining Factors. CERDI - Université d'Auvergne, 1-12.

Pittock, J., Hussey, K and McGlennon, S. (2013) Australian climate, energy and water policies: conflicts and synergies. Australian Geographer, 44 (1): 3-22.

https://doi.org/10.1080/00049182.2013.765345

Randhawa, A. and Kumar, A. (2017) Exploring sustainability of smart development initiatives in India. International Journal of Sustainable Built Environment, 6 (2): 701-710. https://doi.org/10.1016/j.ijsbe.2017.08.002

Romero-Lankao, P., McPhearson, T. and Davidson, D.J. (2017) The food-energy-water nexus and urban complexity. Nature Climate Change, 7(4): 233-235. https://doi.org/10.1038/ncl imate 3260

Roy, A. (2018) Nagpur Municipal Corporation plans to build 3rd sewage treatment plant. The Times of India. Available online: https://timesofindia.indiatimes.com/city/nagpur/nmcplans-to-build-3rd-stp/articleshow/62937953.cms (Accessed on 30th May 2020)

Roy, A. (2019) Nagpur: Genco to add two new 660MW units in highly polluted. The Times of India. Available online: https://timesofindia.indiatimes.com/city/nagpur/genco-to-add-twonew-660mw-units-in-highly-polluted-koradi/articleshow/68225367.cms (Accessed on 30th May 2020)

Schlör, H., Venghaus, S. and Hake, J. (2018) The FEW-Nexus city index - Measuring urban resilience. Applied Energy, 210: 382-392. https://doi.org/10.1016/j.apenergy.2017.02.026

SCM (2015) Smart Cities Mission, Ministry of Housing and Urban Affairs, Government of India. Available online: http://smartcities.gov.in/ (Accessed on 22nd February 2020)

Singh, C. and Rahman, A. (2018) Urbanising the Rural: Reflections on India's National Rurban Mission. Asia \& the Pacific Policy Studies, 5(2): 370-377. https://doi.org/10.1002/app5.234

Sivaramakrishnan, L. and Sar, M. (2014) Rural Urban Linkages: A Study Around Nalhati Municipality. International Journal of Development Research, 4(3): 721-726. https://www.journalijdr.com/rural-urban-linkages-study-around-nalhati-municipality 
Srivastava, N. and Shaw, R. (2013) Establishing Urban-Rural Linkage Elements for Growth and Poverty Reduction in India. Asian Journal of Environment and Disaster Management, 5 (1): 81-102. DOI: 10.3850/S179392402013002615

Stephan, R.M., Mohtar, R.H., Daher, B., Irujo, A.E., Hillers, A., Ganter, J.C., Karlberg, L., Martin, L., Nairizi, S., Rodriguez, D.J. and Sarni, W. (2018) Water-energy-food nexus: a platform for implementing the Sustainable Development Goals. Water International, 43(3): 472-479. https://doi.org/10.1080/02508060.2018.1446581

Sukhwani, V., Shaw, R., Mitra, B.K. and Yan, W. (2019) Optimizing Food-Energy-Water (FEW) Nexus to Foster Collective Resilience in Urban-Rural Systems. Progress in Disaster Science, 1. http://dx.doi.org/10.1016/j.pdisas.2019.100005

Tacoli, C. (1998) Rural-urban interactions: a guide to the literature. Environment and Urbanization, 10 (1) 147-166. https://doi.org/10.1177/095624789801000105

UN-Habitat (1976) The Vancouver Declaration on Human Settlements. Habitat: United Nations Conference on Human Settlements, Vancouver, Canada. https://mirror.unhabitat.org/downloads/docs/The_Vancouver_Declaration.pdf

UN-Habitat (2017) Implementing The New Urban Agenda By Strengthening Urban-Rural Linkages-Leave No One And No Space Behind. United Nations Human Settlements Programme. Available at: https://unhabitat.org/books/implementing-the-new-urban-agendaby-strengthening-urban-rural-linkages/ (Accessed on 22nd February 2020)

UNDP (2015). Sustainable Development Goals (SDGs). United Nations Development Programme. Available at: http://www.undp.org/content/undp/en/home/sustainabledevelopment-goals.html (Accessed on 22nd February 2020)

UNDRR (2015) Sendai Framework for Disaster Risk Reduction 2015-2030 'SFDRR'. United Nations Office for Disaster Risk Reduction. 32 pp. Available online: https://www.undrr.org/publication/sendai-framework-disaster-risk-reduction-2015-2030 (accessed on 24th February 2020)

UrbanEmissions.info (2019) City - Nagpur, India. Available online: http://www.urbanemissions.info/india-apna/nagpur-india/ (Accessed on 22nd February 2020)

USGS (2019) Raster image sourced from USGS Earth Explorer and modified using ArcGIS. https://earthexplorer.usgs.gov/

van Leeuwen, E.S. and Nijkamp, P. (2006) The Urban-Rural Nexus- A Study on Extended Urbanization and the Hinterland, Studies in Regional Science, 36(2): 283-303. https://doi.org/10.2457/srs.36.283

Wadoda ICAP (2017) Integrated Cluster Action Plan, Wadoda Cluster. National Rurban Mission, Ministry of Rural Development, Government of India. https://rdd.maharashtra.gov.in/sites/default/files/Wadoda_ICAP_Report_Final.pdf 
WEF (2018) The Global Risks Report 2018 - 13th edition, Insight report. World Economic Forum, Geneva, Switzerland. http://www3.weforum.org/docs/WEF_GRR18_Report.pdf

Wilbanks, T.J. and Fernandez, S.J. (2013) Climate Change and Infrastructure, Urban Systems, and Vulnerabilities: Technical Report for the U.S. Department of Energy in Support of the National Climate Assessment. Washington, DC: Island Press. Available at: http://www.ourenergypolicy.org/wp-content/uploads/2014/03/document_cw_01.pdf

Yigitcanlar, T. (2010a) Knowledge-based development of cities : a myth or reality? In: Proceedings of REvive MTY forum 2010, 3 - 4 June 2010, Monterrey, Mexico.

Yigitcanlar, T. (2010b) Making space and place for the knowledge economy: Knowledgebased development of Australian cities. European Planning Studies, 18(11): 1769-1786. https://doi.org/10.1080/09654313.2010.512163

Yigitcanlar, T. and Lönnqvist, A. (2013) Benchmarking knowledge-based urban development performance: Results from the international comparison of Helsinki. Cities, 31: 357-369. https://doi.org/10.1016/j.cities.2012.11.005

Zavratnik, V., Kos, A. and Duh, E.S. (2018) Smart Villages: Comprehensive Review of Initiatives and Practices. Sustainability, 10(7), 2559. https://doi.org/10.3390/su10072559 